\title{
LARVAL DEVELOPMENT OF HEXAPANOPEUS PAULENSIS RATHBUN, 1930 (CRUSTACEA, BRACHYURA, XANTHIDAE) UNDER LABORATORY CONDITIONS
}

\author{
Adilson Fransozo \\ Fernando Luiz Medina Mantelatto \\ Maria Lucia Negreiros-Fransozo
}

\begin{abstract}
Four zoeal stages and one megalopa stage of Hexapanopeus paulensis Rathbun, 1930 were obtained from eggs of ovigerous females from the northern coast of São Paulo State, Brazil. The experiments were performed in a climatically controlled room at $24 \pm 1^{\circ} \mathrm{C}$ at a salinity of $34.5 \%$, and the animals were fed with newly hatched Artemia salina nauplii. All larval stages are illustrated and described in detail. The complete larval development consists of 4 zoeal stages and 1 megalopal stage.

The main morphological characters that allow the identification of the zoeae and megalopa of $\mathrm{H}$. paulensis are analyzed with respect to the other species of Xanthidae's family from southern and southeastern Brazilian coast.
\end{abstract}

\section{INTRODUCTION}

Containing over 130 genera and almost 1000 species, the Xanthidae is by far the largest brachyuran family. It is, therefore, not surprising that it is difficult to frame a larval description that will cover all known xanthid zoeae and, at the same time, distinguish them from those of all other brachyurans. One reason for this difficulty is undoubtedly, as in most other families, the fact that so few xanthid larvae have been described and many of the available descriptions are inadequate or unreliable. But, a further reason is that there is a considerable range of form amongst xanthid zoeae and the family seems to contain several distinct groups (RICE, 1980).

Along the sourthern and southeastern Brazilian coast the xanthids form the second most numerous family, of the 21 families known, having 15 genera, and about 29 species (Melo, 1985). Of these, only Panopeus herbstii, Hexapanopeus angustifrons, Pilumnus dasypodus, Menippe nodifrons, Eurytium limosum, Panopeus occidentalis, Panopeus bermudensis, Panopeus americanus, Eurypanopeus abbreviatus, Eriphia gonagra and Fanopeus austrobesus, have been studied with reference to the larval development by, respectively, Costlow \& Bookhout (1961, 1966), Sandifer (1974), Scotto (1979), Kurata et al. (1981), Ingle (1985), Martin et al. (1985), Negreiros-Fransozo (1986, 1986a), Fransozo (1987) and Montú et al. (1988).

For the genus Hexapanopeus, containing 9 species, the first paper on larvae dealt with the pre-zoeal stage of $H$. angustifrons (Hyman, 1925). Since then, only one paper 
about the larval development in this genus has appeared (Costlow \& Bookhout, 1966), with detailed descriptions of all stages of the same species in North America.

The present paper describes the larval stages of Hexapanopeus paulensis obtained in the laboratory. Larvae are compared to the other species of Xanthidae that occur on the southern and southeastern Brazilian coast.

\section{MATERIAL AND METHODS}

Hexapanopeus paulensis Rathbun, 1930, is found in the western Atlantic from South Carolina, Florida, to the Gulf of Mexico and Brazil (Melo, 1985). This species is identifiable by the presence in the carpus of the cheliped with about 10-15 irregular, coarsely granulate, knoblike tubercules.

The ovigerous females of $H$. paulensis were obtained by otter-trawl, between 6 and $8 \mathrm{~m}$ depth, on a sandy bottom, near Ubatuba, São Paulo, Brazil, $23^{\circ} 26^{\prime} \mathrm{S}$ and $45^{\circ}$ $05^{\prime} \mathrm{W}$. The specimens were kept alive in the laboratory in 10 liter aquaria with sea water. Temperature was about $24 \pm 1{ }^{\circ} \mathrm{C}$, salinity was normal for the region $(34.5 \%)$, and aeration was continuous until the larvae hatched to zoeae I. The newly hatched larvae were removed from aquaria with a filler and transfered to isolated in compartiments acrylic vessels of $50 \mathrm{ml}$, with filtered and previously aerated sea water of $34.5 \%$.

The rearing experiments were performed in july 1989, during which about 50 larvae were used. In order to calculate the duration of the stages and the survival rate, the data concerning the larvae from a single ovigerous female were used. About 20 newly hatched Artemia salina nauplii were offered daily as food for each larva.

Larvae of each stage were fixed an preserved in a 1:1 mixture of ethyl alcohol $(96 \%)$ and glycerin. The exuviae were kept in pure glycerin.

The illustrations and measurements of each stage were made from live and fixed material, as well as from exuviae with the help of a microscope provided with a camera lucida. In the morphological descriptions the setation is listed from proximal to distal on the segments.

The larvae were reared in the laboratory following the methods of NegreirosFransozo et al. (1989). The terminology used by Rice (1980) and Fransozo \& Hebling $(1982,1986)$ is adopted here.

\section{RESULTS}

The larval development of $H$. paulensis consists of four zoeal stages and one megalopa. The existence of a pre-zoea stage was not verified.

The duration of each stage, its survival and mortality are presented in Figura 1. The mean accumulated duration of zoeae I, II, III and IV are, respectively, $11.15 \pm$ $3.01 ; 20.68 \pm 2.98 ; 29.85 \pm 4.59$ and $51.67 \pm 4.62$. in days. The duration of the megalopa stage was not calculated.

The morphological descriptions of the larval stages are the following:

\section{ZOEA I}

CARAPACE (Fig. 2-a): one dorsal and the rostral spine, and a pair of lateral spines.

ABDOMEN (Fig. 2-b): 5-segmented, with a distinct pair of lateral knobs on the second and third segments. 


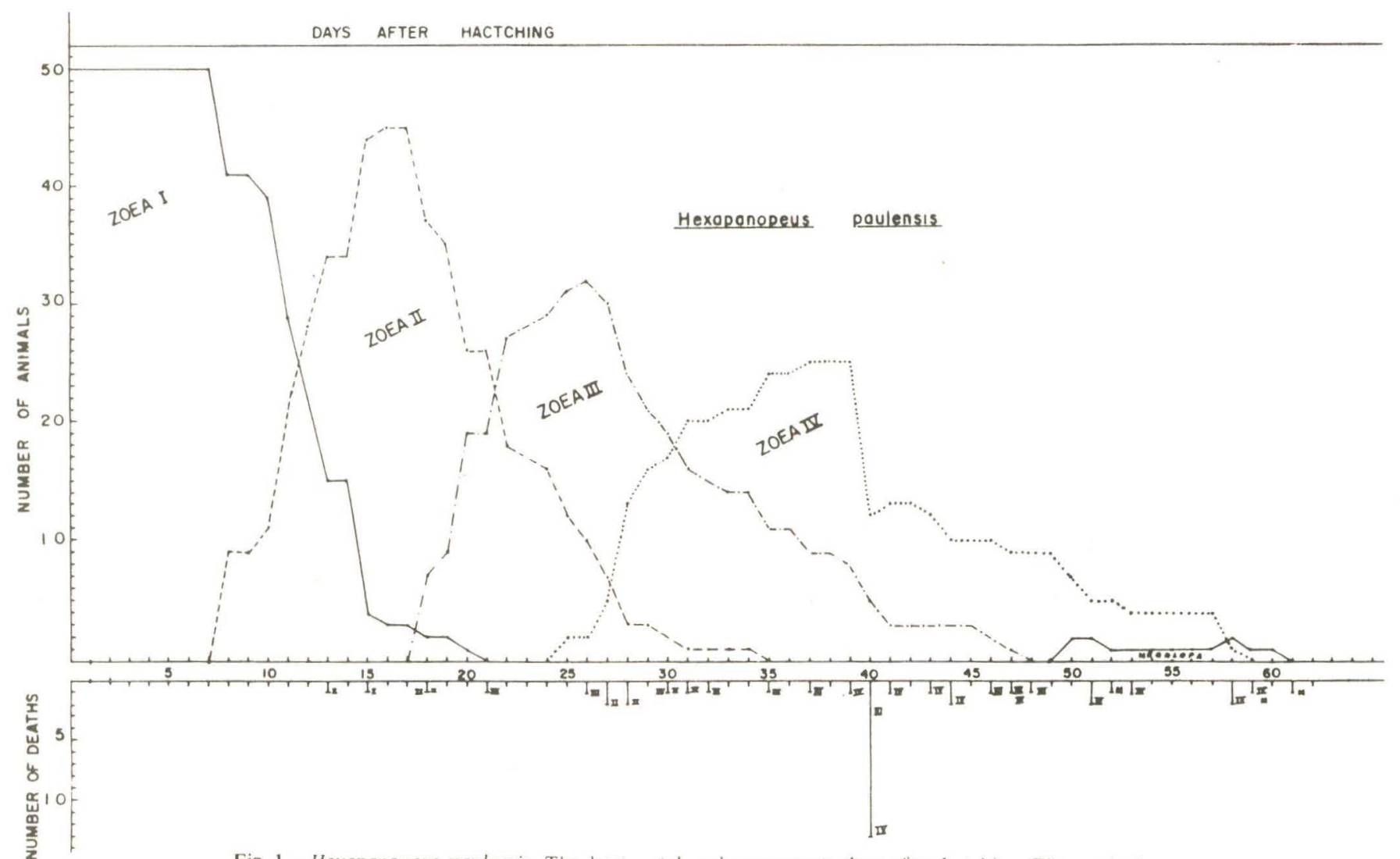

Fig. 1 - Hexapanopeus paulensis. The horizontal scale represents days after hatching. The vertical scale represents number of animals. In the lower figure the number of deaths per day is indicated. The symbols I, II, III, IV and M, represents respectively zoea I, zoea II, zoea III, zoea IV and megalopa stages. 
Revta bras. Zool.
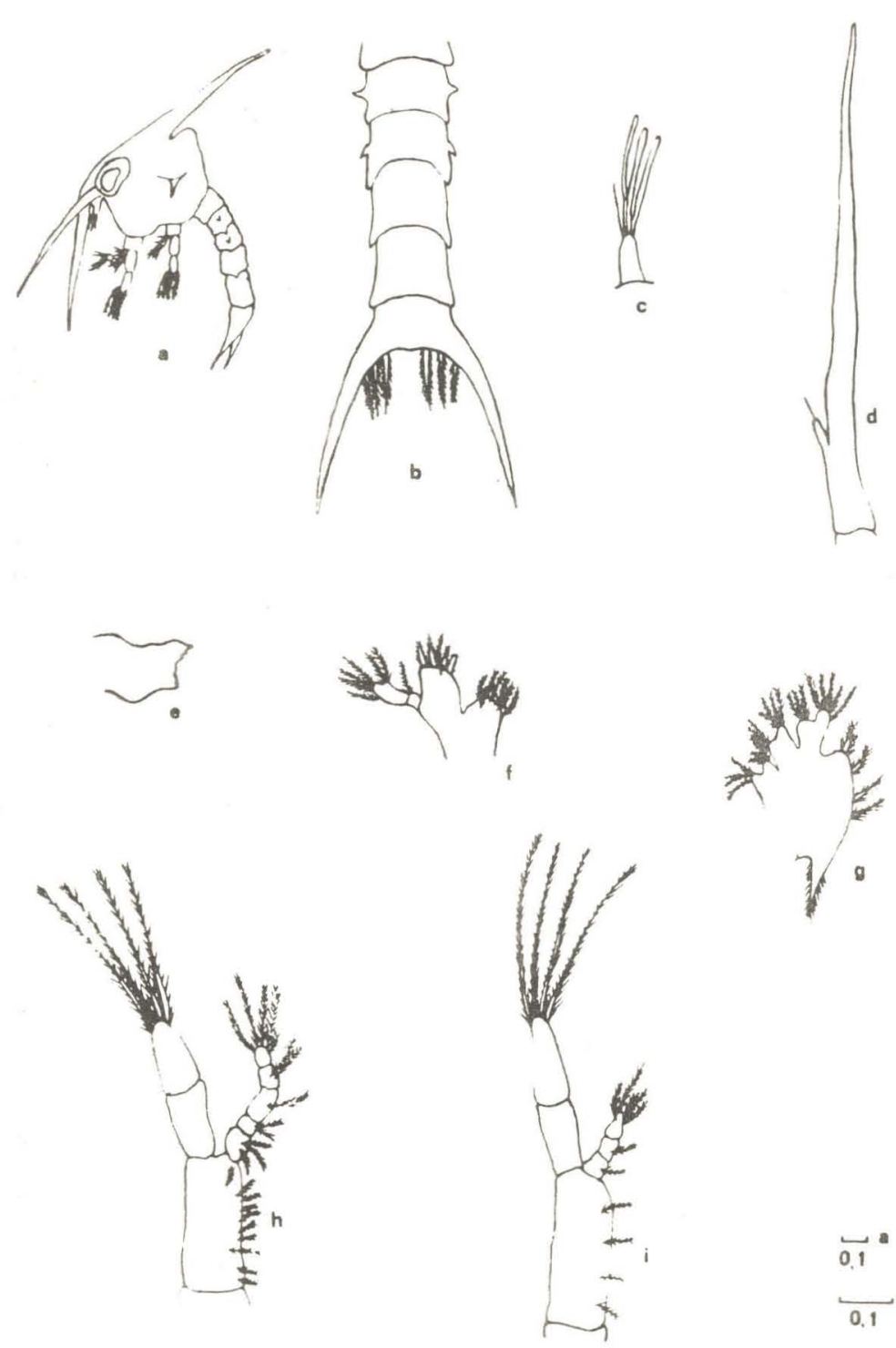

Fig. 2 - Hexapanopeus paulensis. First zoea. a, lateral view; b, abdomen; c, antennule; d, antenna; e, mandible; $f$, maxillule; $g$, maxilla; $h$, first maxilliped and $i$, second maxilliped. Scale $=\mathbf{m m}$. 
Vol. 7(1-2), 1990

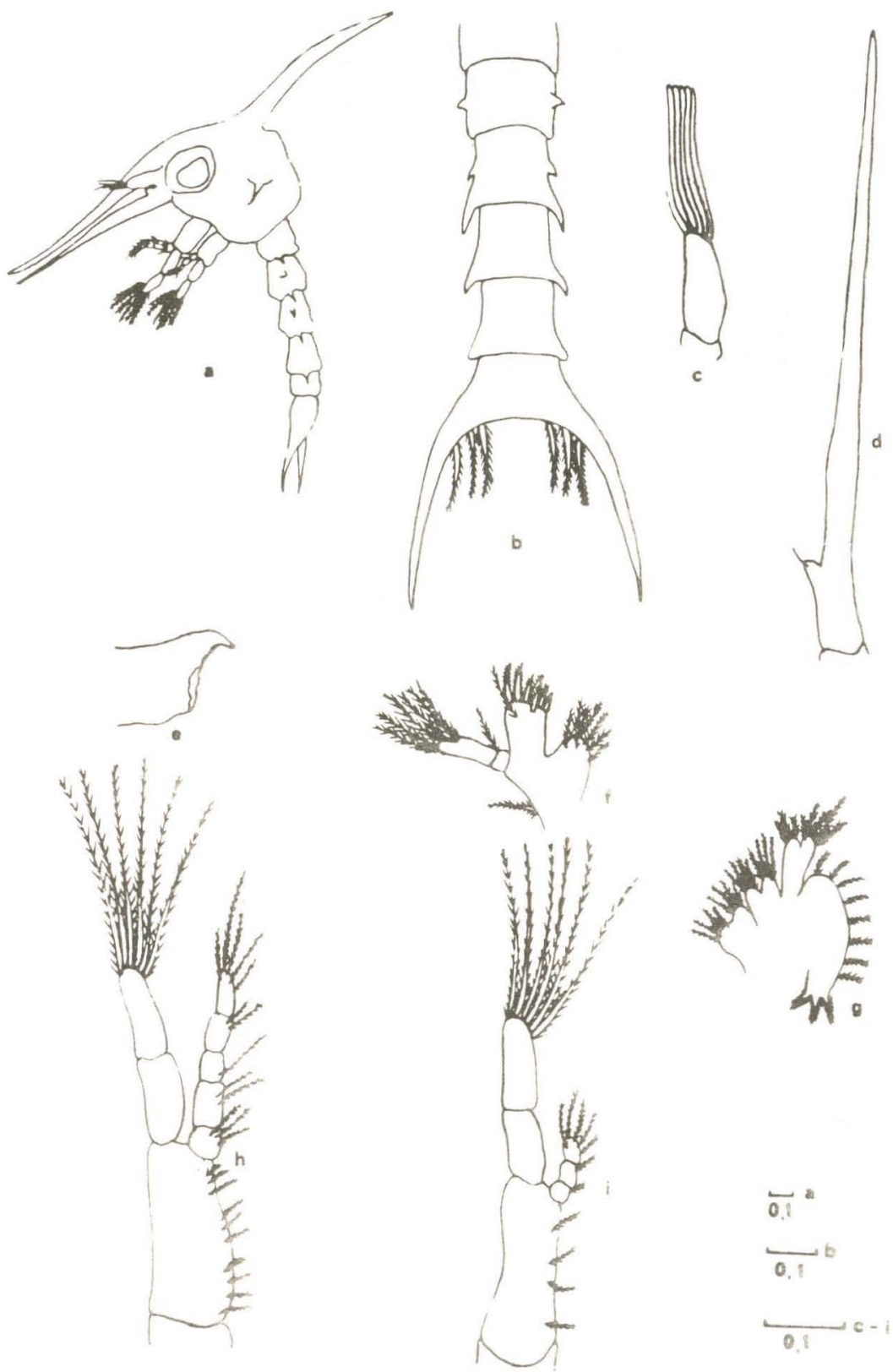

Fig. 3 - Hexapanopeus paulensis. Second zoea. a, lateral view; b, abdomen; c, antennulc; d, antenna; $\mathrm{e}$, mandible; $f$, maxillule; $g$, maxilla; $h$, first maxilliped and $i$, second maxilliped. $\mathrm{Scale}=\mathrm{mm}$. 
Revta bras. Zool.
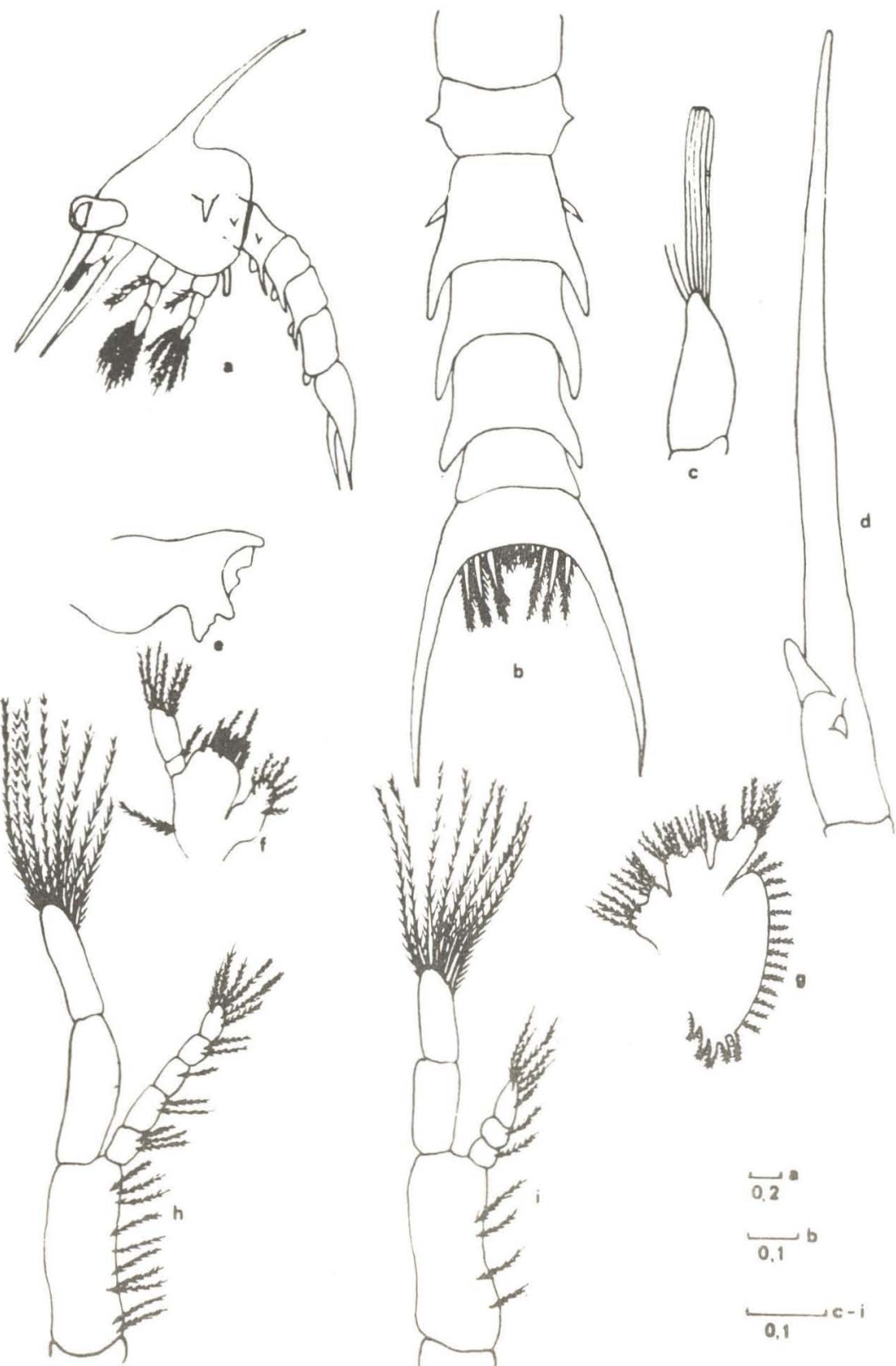

Fig. 4 -Hexapanopeus paulensis. Third zoea. a, lateral view; b, abdomen; c, antennule; d, antenna; $\mathrm{e}$, mandible; $f$, maxillule; $g$, maxilla; $h$, first maxilliped and $\mathrm{i}$, second maxilliped. $\mathrm{Scale}=\mathrm{mm}$. 
Vol. 7(1-2), 1990

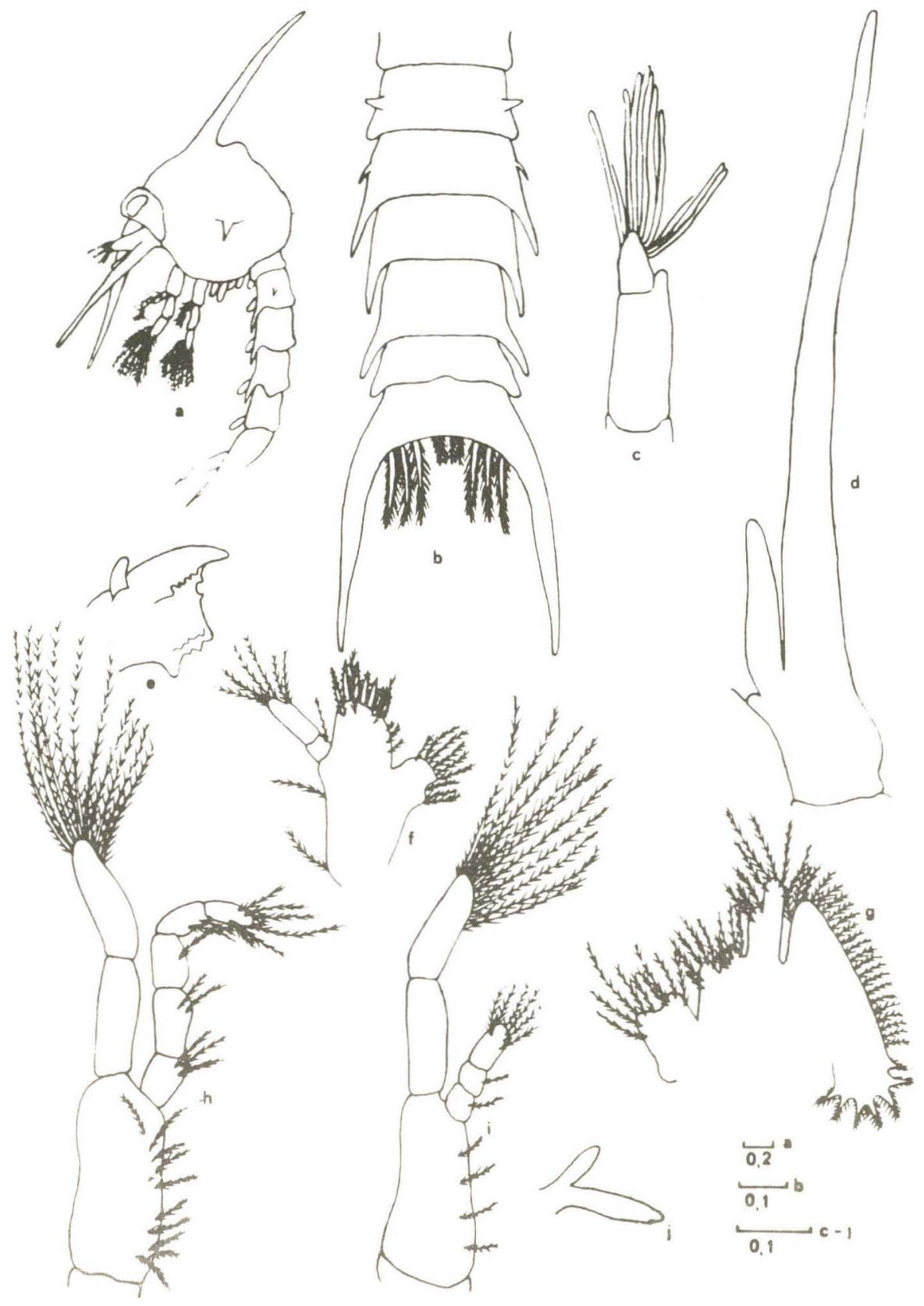

Fig. 5 - Hexapanopeus paulensis. Fourth zoea. a, lateral view; b, abdomen; c, antennule; d, antena; e, mandible; $f$, maxillule; $g$, maxilla; $h$, first maxilliped; $i$, second maxilliped and $j$, third maxilliped. Scale $=\mathrm{mm}$. 
Revta bras. Zool.
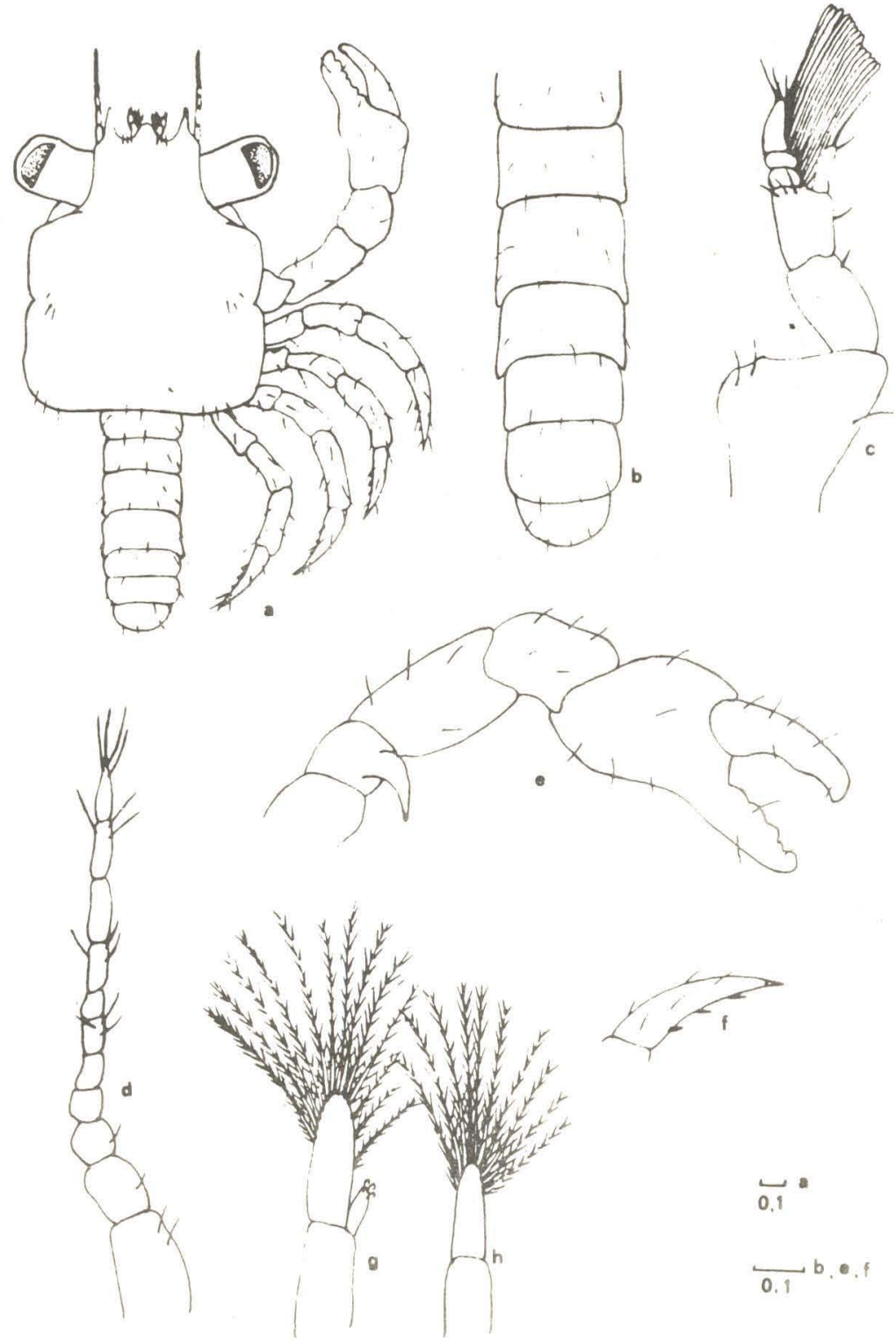

Fig. 6 - Hexapanopeus puslensis. Megu cheliped; $f$, dactyl of pereiopod $5 ; g$, pleopod $3 ; \mathrm{h}$, uropod. Scale $\approx$ mri. 

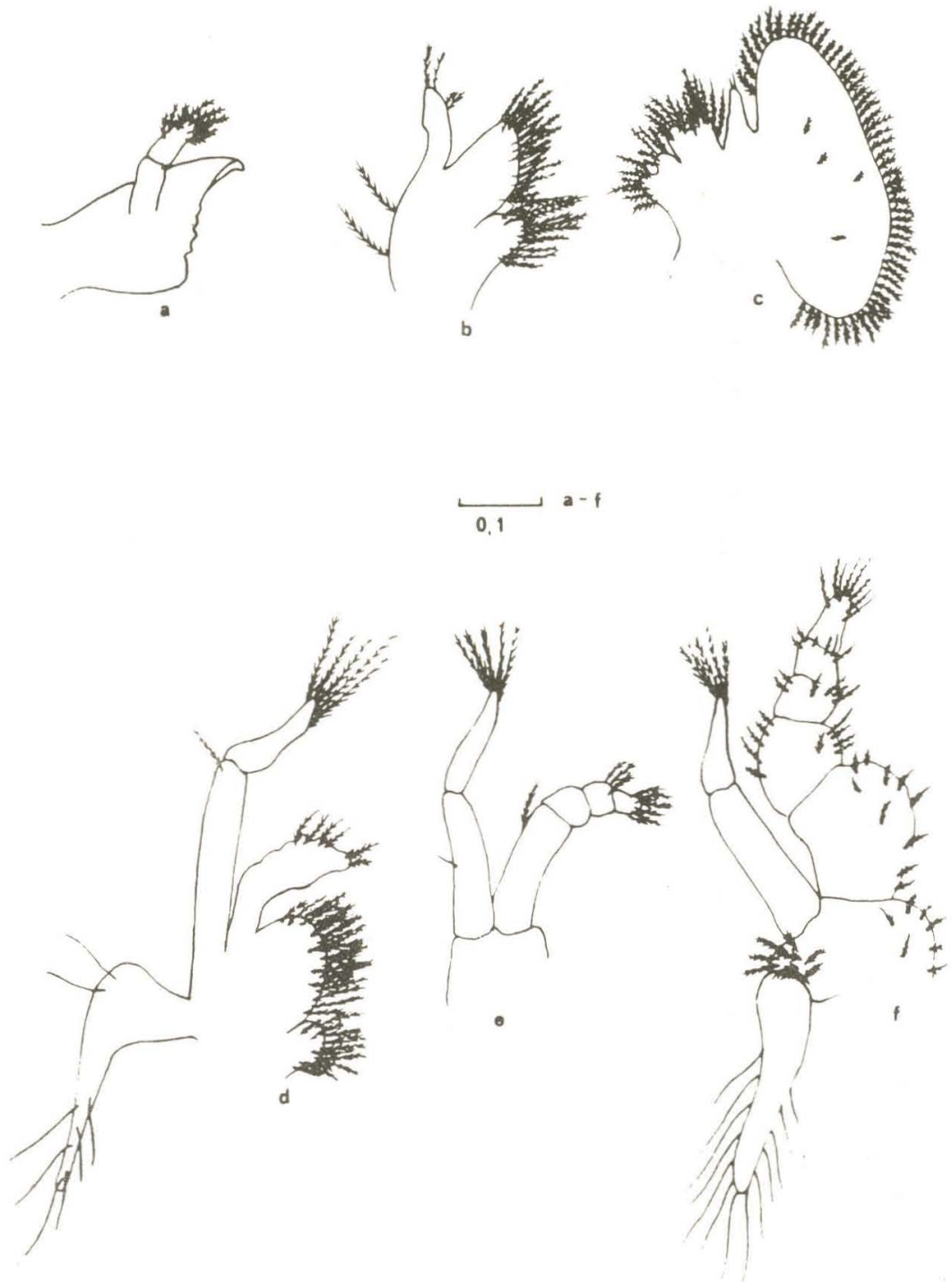

Fig. 7 - Hexapanopeus paulensis. Megalopa. a, mandible; b, maxillule; c, maxilla; d, first maxilliped; $\mathrm{e}$, second maxilliped; $\mathrm{f}$, third maxilliped. Scale $=\mathrm{mm}$. 
TABLE I: Morphological comparation on the first zoeal stages of $H$. paulensis with the other species

from Brazilian southern and southeastern coast. Abreviations: $\mathrm{S}=$ setae, $\mathrm{A}=$ aesthetascs, $\mathrm{SP}=$ spines.

\begin{tabular}{|c|c|c|c|c|c|c|c|c|c|c|c|}
\hline$\frac{\text { Hexapanopeus }}{\text { paulens is }}$ & Hexapanopeus & $\frac{\text { Panopeus }}{\text { herbats }}$ & $\frac{\text { Panopeus }}{\text { berpudens1s }}$ & $\frac{\text { Panopeus }}{\text { ocidentalus }}$ & Panopeus & Panopeus & Eurypanopeus & Expppin & Menzppe & Durytium & $\frac{\text { Pllumus }}{\text { dasppodus }}$ \\
\hline & & & & & orercanus & Austrobesus & ebrevatus & Bonesra & nodifrone & 11monum & dasyoodue \\
\hline Present & Present & Preaent & Aboent & Preaent & Present & Preaent & Preaent & Preaent & Preaent & Prosent & Prosent \\
\hline 3,1 & 4,1 & 3,2 & $3(4), 0$ & 3, 1 & 3. 1 & 3,1 & 2,1 & 3. 0 & 3. 1 & ? & 2,2 \\
\hline Onarned & Unarmed & $1 / 4$ & Onarmed & $1 / 2$ & $\therefore / 2$ & $1 / 2$ & $2 / 2$ & $1 / 2$ & $1 / 2$ & $2 / 3$ & $2 / 3$ \\
\hline Moute & mute & Wanute & Aboent & Minute & Mnute & manute & menute & Developed & Doveloped & Manute & Developed \\
\hline I & I & 1 & v & I & 1 & I & I & III & IV & I & II \\
\hline 1,6 & $1, i$ & 2,6 & 1,6 & 2,6 & 1,6 & 1,6 & 2,6 & 2. 6 & 2.4 & 1,6 & 2,6 \\
\hline 4. 1 & 4,1 & 4,1 & 4,1 & 3. 1 & 4,2 & 4,1 & 4. 1 & 4,1 & 4,1 & ? & 4,1 \\
\hline $\begin{array}{l}10 \\
3,2,7,2,5\end{array}$ & $3,2,1,2,5$ & $?_{3,2,1,2,5}$ & ${ }_{3,2,1,2,4}$ & $\begin{array}{l}10 \\
3,2,1,2,5\end{array}$ & $\begin{array}{l}10 \\
3,2,1,2,5\end{array}$ & $\begin{array}{l}10 \\
2,2,1,2,5\end{array}$ & ${ }_{3,2,1,2,5}$ & $\begin{array}{l}10 \\
2,2,1,2,5\end{array}$ & $\begin{array}{l}10 \\
3,2,1,2,5\end{array}$ & $\hat{3}_{3,2,1,2,5}$ & $\begin{array}{l}10 \\
3,2,1,2,5\end{array}$ \\
\hline $4,1,5$ & $3 ?$ & $?$ & 3 & 4 & 4 & 4 & 4 & 4 & 4 & $?$ & $\hat{1}, 1,6$ \\
\hline $1,1,5$ & $1,1,5$ & $1,1,5$ & $1,1,3$ & $1,1,5$ & $1,1,5$ & $1,1,4$ & $1,1,4$ & $1,1,6$ & $0,1,4$ & ? & $1,1,6$ \\
\hline Nesent & Absent & $30,40,50$ & Abeent & $30,40,50$ & $30,42,50$ & $39,40,50$ & $30,4 e, 50$ & Aboent & 50 & Absent & Absent \\
\hline Sanooth & Smooth & Seooth & Smootb & Spinuione & Smooth & Smooth & Smooth & Smootb & Smooth & Seooth & Splnuzose \\
\hline 0,0 & 0,0 & 2,2 & 1.0 & 1,2 & 1,1 & 1,2 & 1.2 & 1,2 & 1,2 & 1,2 & 2,2 \\
\hline
\end{tabular}


Vol. 7(1-2), 1990

TELSON (Fig. 2-b): trapezoidal, with long slender furcae; posterior margin with 3 pairs of stout serrate setae.

ANTENNULE (Fig. 2-c): unsegmented, conical with 3 aesthetascs and 1 simple setae. ANTENNA (Fig. 2-d): protopod subequal to rostrum in lenght, unarmed, tapering distally; exopod rudimentar, with a minute single setae.

MANDIBLE (Fig. 2e): concave inner surface; teeth asymetrically dentate.

MAXILLULE (Fig. 2-f): endopod 2-segmented, proximal article with 1 setae and distal article with 4 terminal plumose setae and 2 subterminal; basal endite with 4 plumose spines and 1 plumose setae; coxal endite with 7 plumose setae.

MAXILLA (Fig. 2-g): scaphognathite with 4 plumose setae on outer margin; distal portion tappering to a thin plumose process, endopod with 5 terminal pulmose setae and 3 subterminal; basal endite bilobed $4+4$ plumose setae and coxal endite bilobed with $3+4$.

FIRST MAXILLIPED (Fig. 2-h): basipod with 10 median plumose setae; endopod is 5 -segmented with, respectively, 3, 2,1,2 and 5 plumose setae; exopod is 2 -segmented with 4 natatory plumose setae

SECOND MAXILLIPED (Fig. 2-i): basipod with 4 median plumose setae; endopod is 3 -segmented with, respectively, 1,1 and 5 plumose setae; exopod is 2 -segmented with 4 natatory plumose setae.

THIRD MAXILLIPED: absent.

\section{ZOEA II}

CARAPACE (Fig. 3-a): in general as in zoea $\mathrm{I}$.

ABDOMEN and TELSON (Fig. 3-b): similar to those of zoea I; segments 3 and 4 with long posterolateral spines overlapping each following segments, respectively.

ANTENNULE (Fig. 3-c): unsegmented, conical, with 4 aesthtascs and 1 simple setae. ANTENNA (Fig. 3-d): as in zoea I.

MANDIBLE (Fig. 3-e): does not present any significant differences from that of the previous stage.

MAXILLULE (Fig. 3-f): endopod with the same setae numbers, as in the zoea I; basal endite with 7 plumose spines and 1 plumose setae and coxal endite with 7 plumose setae; protopod with 1 plumose setae.

MAXILLA (Fig. 3-g): scaphognathite with 8 marginal plumose setae and the distal portion with 3 plumose process; endopod as in zoea 1 ; basal endite bilobed with $4+4$ plumose setae and coxal endite bilobed with $4+4$ plumose setae.

FIRST MAXILLIPED (Fig. 3-h): basipod and endopod as in the zoea 1; exopod 2segmented with 6 natatory plumose setae.

SECOND MAXILLIPED (Fig. 3-i): basipod and endopod as in the zoea I; exopod 2-segmented with 6 natatory plumose setae.

THIRD MAXILLIPED: absent.

\section{ZOEA III}

CARAPACE (Fig. 4-a): as in previous stage.

ABDOMEN (Fig. 4-b): segments 3, 4 and 5 with posterolateral spines and pleopod buds developing on segments 2-6. 
TELSON (Fig. 4-b): as in previous stages, but with 4 short setae on posterior margin.

ANTENNULE (Fig. 4-c): unsegmented, with 5 aesthetascs of the same lenght and 2 simple setae.

ANTENNA (Fig. 4-d): endopod rudimentary.

MANDIBLE (Fig. 4-e): more evident incisive and molar processes.

MAXILLULE (Fig. 4-f): endopod, protopod and coxal endite as in zoea II; basal endite with 8 plumose spines and 2 plumose setae.

MAXILLA (Fig. 4-g): scaphognathite with 14 marginal plumose setae, distal portion with 5 plumose process; endopod with same setae number as in zoea II; basal endit bilobed with $5+5$ plumose setae and coxal endite bilobed with $4+4$.

FIRST MAXILLIPED (Fig. 4-h): basipod as in zoea II; endopod with, respectively, $3,2,1,2$ and 6 plumose setae; exopod is 2 -segmented with 8 natatory plumose setae.

SECOND MAXILLIPED (Fig. 4-i): basipod as in zoea II; endopod with, respectively, 1,1 and 6 plumose setae; exopod is 2 -segmented with 8 natatory plumose setae.

THIRD MAXILLIPED: absent.

\section{ZOEA IV}

CARAPACE (Fig. 5-a): in general as in zoea III.

ABDOMEN and TELSON (Fig. 5-b): in general as in zoea III.

ANTENNULE (Fig. 5-c): bissegmented, with 9 aesthetascs and 2 simple setae.

ANTENNA (Fig. 5-d): endopod longer than in previous stage.

MANDIBLE (Fig. 5-e): distinct teeth on incisive and molar processes and beginning of a palp.

MAXILLULE (Fig. 5-f): endopod with the same setae numbers as in zoea III; basal endite with 7 plumose spines and 5 plumose setae; coxal endite with 9 plumose setae; protopod with 2 plumose setae.

MAXILLA (Fig. 5-g): scaphognathite with 22 marginal plumose setae and the distal portion with 7 plumose process; endopod as in zoea III; basal endite bilobed with $5+5$ and coxal endite bilobed with $4+5$.

FIRST MAXILLIPED (Fig. 5-h): basipod and endopod with same setae numbers as in zoea III; exopod is 2 -segmented with 10 natatory plumose setae.

SECOND MAXILLIPED (Fig. 5-i): basipod and endopod with same setae number as in zoea III; exopod is 2 -segmented with 10 natatory plumose setae.

THIRD MAXILLIPED (Fig. 5-j): rudimentary.

\section{MEGALOPA}

CARAPACE (Fig. 6-a): subquadrate, frontal region with slight medial depression anteriorly, sharp anterolateral homs, rostrum blunt; short setae over broad medio-posterolateral region.

ABDOMEN (Fig. 6-b): 6 segments plus telson, all covered sparsely with minute setae. TELSON (Fig. 6-b): posterior margin rounded and 4 dorsal setae.

ANTENNULE (Fig. 6-c): peduncle 3-segmented with 3,1 and 4 setae, respectively; ventral flagellum unsegmented with 2 terminal setae; dorsal flagellum 3 -segmented with 6 , 6 and 3 aesthetascs and 3 setae on the distal segment.

ANTENNA (Fig. 6-d): peduncle 3-segmented with 2, 1 and 1 setae; flagellum 8-segmented with $0,0,3,0,3,0,3$, and 4 setae. 
MANDIBLE (Fig. 7-a): asymetrical with distinct teet on incisive process; palp 2-segmented, with 9 plumose setae on the distal segment.

MAXILLULE (Fig. 7-b): protopod area with 2 plumose setae; endopod unsegmented with 4 setae; basal endite with 15 plumose spines and 10 plumose setae; coxal endite with 10 plumose setae.

MAXILLA (Fig. 7-c): scaphognathite with 57 to 59 fringing setae; endopod with 2 setae; basal endite bilobed with $8+6$; coxal endite bilobed with $5+8$.

FIRST MAXILLIPED (Fig. 7-d): exopod 2-segmented, setation 1 and 5; endopod unsegmented, with 6 setae; basal endite with 20 setae; coxal endite with 12 to 14 setae; epipod with 8 long naked setae.

SECOND MAXILLIPED (Fig. 7e): exopod 2-segmented, setation 1 and 5; endopod 4segmented, setation 1, 0, 3 and 7 to 8 .

THIRD MAXILLIPED (Fig. 7-f): exopod 2-segmented, setation 0 and 5; endopod 5segmented, setation 10 to $12,10,6,6$ and 8 to 9; epipod with 13 long naked setae; protopod with 16 to 18 plumose setae.

PEREIOPODS: sparsely covered by setae. Chelipeds (Fig. 6e) with large ischial recurved hook and irregular teeth on fingers. Dactyl of pereiopods 5 (Fig. 6-f) with 3 strong serrate ventral spines.

PLEOPODS (Fig. 6-g): the four pairs of pleopods (P12 to P15) with 13 natatory setae on the exopod and the endopod with 3 hooked setae.

UROPOD (Fig. 6-h): with 10 natatory setae on the exopod; endopod absent.

\section{DISCUSSION}

The occurrence of four zoeal stages and one megalopa stage in common of the majority of the species of the Xanthidae family studied under this aspect, and once more it was confirmed on the study of $H$. paulensis.

The mean duration of the zoeal phase of $H$. paulensis was higher than in the other xanthid's of the southern and southeastern Brazilian coast. However, it could be seen that used the salinity for the rearing of each of them varied according to the sites of occurrence of the species, and the salinity is considered one of the environmental factors which can affect the duration of the larval stages (Fransozo \& Negreiros-Fransozo, 1986 and Negreiros-Fransozo \& Fransozo, in press).

Several workers, amont them, Hyman (1925), Lebour (1928, 1944), Aikawa $(1929,1933,1937)$ and Wear $(1970)$ tried to propose one classification of the Xanthidae's larvae based mainly on the exopod antennal morphology and on the telsonal and carapacial spine. Such classification does not correspond with that based on the adult forms.

Martin et al. (1985), studying the larval development of Panopeus bermudensis, verified that one reason for its discrepancies is the fact that telsonal, and especially carapacial morphology and spination very greatly among xanthid larvae of even congeneric species often differ markedly in characters of the carapace. But the morphology of the antennal exopod varies much less than does carapacial morphology; consequently many workers have employed this character in separating xanthid larvae

Rice (1980) established four zoeal groups (I to IV) of Xanthidae based mainly on antennal exopod and mouthparts setation. Martin (1984) added two more groups (V and VI), including the larvae of Micropanope (sensu lato) and of Panopeus bermudensis. 
From this present analysis with the Xanthidae's larvae, we get to the conclusion that Hexapanopeus genus can be considered a new group by the fact of having:

a) common features with groups I and VI (distal segment of the maxilula endopod with 6 setae; maxilla endopod with 8 setae; basal segment of the first and second maxillipeds endopods with, respectively, 3 and 1 setae);

b) intermediate features between groups I and VI (smooth antennal protopod (VI) and rudimentar antennal exopod with 1 apical setae (I));

c) exclusive features of this new group (telson with smooth furcae deprived of spines or setae).

However, the proposition of a new group involving the Hexapanopeus genus is premature, in view of the fact that features can be variations of the group I. A similar case involving $P$. bermudensis larvae was discussed by Martin et al. (1985).

After the analysis of the larval characters of $H$. paulensis with that of $H$. angustifrons, one very marked similarity was found, particularly in the first zoeal stage. The morphological differentiation can only be based on the number of antennule aesthetascs. The main variability in the megalopa phase occur on the number of the antennal segments, number of setae of the maxillule endopod, maxilla scaphognathite and on the second maxilliped endopod.

A comparative study of the first larval stage of $\mathrm{H}$. paulensis, with the other species which occur in the Brazilian southern and southeastern coast, is possible due to several morphological characters analysed together, and are demonstrated in Table I.

According to Rice (1980) and Martin et al. (1985), we believe that the zoeal evidence suggests several distinct evolutive lines in the Xanthidae groupment and, that only with detailed larval studies of one major number of genera and species associated with the adult and juvenile features, we can delimit the systematic positions and the phylogenetic lines of this group.

\section{ACKNOWLEDGMENTS}

We are thank to the "Conselho Nacional de Desenvolvimento Científico e Tecnológico - (CNPq)" and to the "Fundação para o Desenvolvimento da UNESP FUNDUNESP" for the finnancial support. We are extremely gratefull to Dr. Gustavo A.S. de Melo, Museu de Zoologia da USP, for the identification of the species.

\section{REFERENCES}

AIKAWA, H. 1929. On the larval forms of some Brachyura. Rec. Oceanogr. Wks. Japan 2: 17-55.

AIKAWA, H. 1933. On larval forms of some Brachyura, paper II; a note on indeterminable zoeas. Rec. Oceanogr. Wks. Japan 5: 124-254.

AIKAWA, H. 1937. Further notes on brachyuran larvae. Rec. Oceanogr. Wks. Japan, 12: 117-120.

COSTLOW, J.D., Jr. \& C.G. BOOKHOUT 1961. The larval stages of Panopeus herbstii MilneEdwards reared in the laboratory. Jour. Elisha Mitchell Sci. Scc., 77: 33-42.

COSTLOW, J.D., Jr \& C.G. BOOKHOUT 1966. Larval development of the crab Hexapanopeus angustifrons. Chesapeake Sci., 7 (3): 148-156.

FRANSOZO, A. 1987. Desenvolvimento larval de Eriphia gonagra (Fabricius, 1781) (Decapoda, Xanthidae) em laboratório. Revta. Bras. Zool., São Paulo, 4 (3): 165-179.

FRANSOZO, A. \& N.J. HEBLING, 1982. Desenvolvimento pós-embrionário de Mithrax hispidus (Herbst, 1790) (Decapoda, Majidae) em laboratório. Ciên. Cult., 34 (3): 385-395.

FRANSOZO, A. \& N.J. HEBLING, 1986. Desenvolvimento larval de Sesarma (Holometopus) rectum Randall, 1840 (Decapoda, Grapsidae) em laboratório. Rev. Brasil. Biol., 46 (2): 353-364. 
Vol. 7(1-2), 1990

FRANSOZO, A. \& M.L. NEGREIROS-FRANSOZO 1986. Influência da salinidade no desenvolvimento larval de Eriphia gonagra (Fabricius, 1781) e Sesarma (Holometopus) rectum Randall, 1840 (Crustacea, Decapoda) em laboratório. Rev. Brasil. Biol., 46 (2): 439-446.

HYMAN, O.W. 1925. Studies on the larvae of the crabs of the family Xanthidae. Proc. U.S. Nat. Mus., 67: 1-22.

INGLE, R.W. 1985. Larval development of the mud crab Panopeus occidentalis de Saussure, from Bermuda (Crustacea: Xanthoidea: Panopeidae), Bull. Br. Mus. Nat. Hist. (Zool.), 48 (4) : 233 248.

KURATA, H.; R.W. HEARD \& J.W. MARTIN, 1981. Larval development under laboratory conditions of the xanthidae mud crab Eury tium limosum (Say, 1818) (Brachyura: Xanthidae) from Georgia. Gulf. Res. Repts., 7 (1): 19-25.

LEBOUR, M.V. 1928. The larval stages of the Plymouth Brachyura. Proc. Zool. Soc. London, 14 : 473-560.

LEBOUR, M.V. 1944. Larval crabs from Bermuda. Zoologica, 29: 113-128.

MARTIN, J.W. 1984. Notes and bibliography on the larvae of xanthid crabs, with a key to the know xanthid zoeas of the Western Atlantic and Gulf of Mexico. Bull. mar. Sci., 34 (2): 220-239.

MARTIN, J.W.; F.M. TRUESDALE \& D.L. FELDER, 1985. Larval development of Panopeus bermudensis Benedict \& Rathbun, 1891 (Brachyura, Xanthidae) with notes on zoeal characters in xanthid crabs. J. Crust. Biol., 5 (1): 84-105.

MELO, G.A.S. 1985. Taxonomia e padrōes distribucionais ecológicos dos Brachyura (Crustacea, Decapoda) do litoral sudeste do Brasil. 215 pp. USP - São Paulo (Tese de Doutorado).

MONTÚ, M.; K. ANGER; C. DE BAKKER; V. ANGER \& L.L. FERNANDES 1988. Larval development of the Brazilian mud crab Panopeus austrobesus Willians, 1983 (Decapoda: Xanthidae) reared in the laboratory. J. Crust. Biol., 8 (4):594-613.

NEGREIROS-FRANSOZO, M.L. 1986. Desenvolvimento pós-embrionário de Panopeus americanus Saussure, 1857 (Decapoda, Xanthidae) em laboratório. Rev. Brasil. Biol., 46 (1): 173-188.

NEGREIROS-FRANSOZO, M.L., 1986a. Desenvolvimento pós-embrionário de Eurypanopeus abbreviatus (Stimpson, 1860) (Crustacea, Decapoda, Xanthidae) em laboratório. Bolm. Zool., Univ. S. Paulo, 10:19-39.

NEGREIROS-FRANSOZO, M.L. \& A. FRANSOZO (in press). The effect of salinity on the postembryonic development of Panopeus americanus Saussure, 1857 and Eurypanopeus abbreviatus (Stimpson, 1860) (Crustacea, Xanthidae). Atlantica.

NEGREIROS-FRANSOZO, M.L.; A. FRANSOZO \& N.J. HEBLING, 1989. Larval development of Persephona mediterranea (Herbst, 1794) (Brachyura, Leucosiidae) under laboratory conditions. Crustaceana, 57 (2): 177-193.

RICE, A.L. 1980. Crab zoeal morphology and its bearing on the classification of the Brachyura. Trans. Zool. Soc. Lond., 35: 271-424.

SANDIFER, P.A. 1974. Larval stages of the crab Filumnus dasypodus Kingsley (Crustacea, Brachyu$\mathrm{ra}$, Xanthidae) obtained in the laboratory. Bull. Mar. Sci., 24:378-391.

SCOTTO, L.E. 1979. Larval development of the Cuban Stone crab, Menippe nodifrons (Brachyura, Xanthidae) under laboratory conditions with notes on the status of the family Menippidae. Fish. Bull., 77 (2): 359-386.

WEAR, R.G., 1970. Notes and bibliography on the larvae of xanthid crabs. Pacif. Sci., 24:84-89. 